\title{
The Importance of Local Events for Positioning of Tourist Destination
}

\author{
PhD. Assist. Prof. Dr. Iris Mihajlović, \\ Department of economics and Business Economics, University of Dubrovnik
}

Maja Vidak, mag.oec

Department of economics and Business Economics, University of Dubrovnik

\begin{abstract}
This paper highlights levels of influences of local events on the image of region of Konavle, as a microdestination near Dubrovnik. As a municipality Konavle has 32 settlements facing the agriculture and tourism (TZ Konavle. 2016). The aim is to research the influence of the development of local events in Konavle on the destination development in terms of dynamic and competitive market changes. From 2009 Association of Agritourism Konavle has been organizing a local event Scents of Christmas in Konavle. It carried out activities to promote and develop rural tourism in the southernmost region of Croatia (Agritourism Konavle, 2016). It operates through organized events, promotional tour on other rural destinations. For members it organizes workshops, including them in projects. Scientific attitudes of theoreticians in this area, clearly argue the interactivity of selective modalities of tourism and its positive effects on the destination. Based on that attitudes, it was conducted the empirical research by the survey method. The significance of the elements of local event on the recognition and an image of the destination, has been proven. While presenting heritage, an organized event impact on alleviation of the problem of seasonality of every tourist place on the Croatian coast. This event brings together the majority of visitors from micro-destination, Konavle, but also attracts visitors from Dubrovnik. Because of connection between two destinations, it is essential to explore the selected tourism forms, as well their role in the creation of innovative tourist products.
\end{abstract}

Keywords: local event, destination, rural tourism, event tourism, image

\section{Introduction}

The term - event tourism as a link between events and tourism was mentioned in the literature for the first time in 80th of $X X$ century. The basis for the development of manifestation offers destination is growth in the number of participants in tourism, their leisure and qualitative changes in the behavior of tourists. Events are subject to destination marketing complementing the final product. Competition among destinations strengthens and grows. It is necessary to continuously explore new ways of diversification of the existing tourism product, and devise new concepts offers to destinations compete on the market. Growing problem of Croatian tourism, especially the coastal areas, is pronounced seasonality therefore it is necessary to work on resolving this problem. By creating events and activities that take place outside of the tourist season, affect the decrease in number of visitor's gap between summer and winter months. Many destinations have recognized the importance of event for bringing multiple benefits to the destination. These events are organized once or several times to experience unusual emotions. Realization of events claims the organizational abilities, the knowledge and skills thus contributing to the image of the destination. Tourism in Konavle has been developing since 1924, when an Association for development of foreigners in Cavtat was founded. Firstly it was aimed at orientation of dominant fishing local population towards tourism.

Since that time until today, the main tourist resource of Konavle are tangible potentials - cultural and religious heritage and intangible secular heritage. Due to the rural character of destination, Konavle is predisposed to develop (along the events) more forms of selective tourism, among which the most important is rural tourism. Rural tourism is developing by encouraging the development tourism on farming communities, and the development of agritourism (Brailo 1995), whereas the agritourism is defined segment of rural tourism, which enables added value products to farmers. 


\section{.II. Literature Review}

\section{A . A Cronological Overview of the Notion of Events in Human Society}

Historically manifestations are as old as mankind, starting with the ancient ceremony in honor of the gods, medieval knights' celebrations, religious events until today, longest-running and most popular of the Olympic Games (Getz, 1989). The first organized tribal human community transfers stories and songs from generation to generation and organize various tribal ceremony. From era of old civilization of ancient Greece in honor of their deities are dated (eg. Dionysian celebrations), sport events (Olympics, Pythian Games of Ancient Greece, and gladiator games in ancient Rome), and the celebration of important annual events (eg. Chinese New Year).

Through the Middle Ages in Europe are organized mainly religious events and fetes, and knights' tournaments. A contemporary time has not stopped eternal need of people to socialize, compete, entertain, demonstrate, that in a special way to mark some important events in the life of an individual or society. Throughout the events, participants are in attach with historical events, that is evident through the celebration activities, happenings, the emergence of festivals. Events or organized events are a reflection of modern tourism, with regard to culture (music festivals, concerts, exhibitions, events, etc.), sports (regattas, water skiing, etc.), tradition (such as carnivals, gastronomy, and folklore)

The new era, in proportion to the population has increased an economic progress and areas, leading to the formation of different types, shapes and volume of events

\section{B. Scientific Approach to the Term of an Event}

In the 1960s and 1970s the sector of events was not recognized as a separate area. Ritchie and Beliveau (1974) for first time in literature define hallmark events. The industry of events gains momentum in 80's and 90's of the last century. One of the most influential research projects within that era is related to the first large organized travel -Grand Prix (Burns and Mules, 1989).

The requirements of modern tourists are changing with the ever-growing need for a wider range of offers, which provides a wider choice of events. Events offer includes richer and reduce the effect of seasonal fluctuations. An event is global phenomenon whose business becomes increasingly important in a contemporary tourism. The 21 st century captures tourism transparent as the transformation of positive experiences in feelings of satisfaction expressed by number of visits to the destination, frequency of visits, and the continuity of returning to the same. The event (as a term) refers to specific rituals, presentations, performances or celebrations. They are closely, pre-planned and created to commemorate these special events or to achieve specific social, cultural or corporate goals. Event study is an academic area directed the creation of knowledge and theoretical background of the planned events. Its origins could be found in the social sciences and humanities, especially in management and arts. Event management is an area of application of the science of events in practice. Event management alike occupies the private, public and non-profit sector. The term - event tourism started being more often used in 1987 (New Zealand Tourist and Publicity Department).

Getz (2008) argues event tourism in context of destination and a marketing strategy for the realization of the potential economic benefits of the event. Event tourism is an important and rapidly growing segment of international tourism (New Zealand Tourist and Publicity Department, Tourism Report 38, 1987). Events stimulate the intensity and the dynamics of travel. Event management is a fast growing professional field in which tourists constitute a potential market for planned events and the tourism industry has become a vital stakeholder in their success and attractiveness (Getz, 2008: 403). According to Mossberg (2000), the event is a special activity out of the ordinary everyday life. He describes how the events are held regularly, or only once, and that range from small to large with a strong or weak image.

Getz and Cheyne (2002) argue that events over the last decade have become an important means of acquiring advantages and realizing the different economic, social and environmental objectives for many communities and tourist regions. According to Allen et al. (2002) special events describe specific rituals, presentations or anniversaries specifically planned or designed to mark a specific occasion, cultural or organizational goals. Include celebrations, marked significance given the culture of the people, the public opportunities, unique cultural events, but more and promotion functions, operation and product companies. The term refers to specific rituals, presentations, performances or celebrations that closely, preplanned and created to commemorate these special events or achieve specific social, cultural or corporate goals (Getz, 2007). A special event (event) is any public event that takes place live in front of (not) the expected audience. According 
to Mossberg (2000), the event is a special activity out of the ordinary everyday life. He describes how the events are held regularly, or only once, and that range from small to large with strong or weak image. Getz (2005:16) shared definitions of special events from the point of an organizer as a "unique and unrepeatable or rarely (periodic) was held events occurring outside of normal programs or activities of organizations that are sponsored or organized", and in terms of a customer as "an opportunity for relaxation, fun, social or cultural experience that is outside the normal framework of choice or out of everyday events". Events are characterized by unique life experience, concentration on a short period of time and long haul planning. Special events are usually held only once involve high risk, especially financial and security concerns.

Next figure 1 shows the categorizing of events according the size of events.

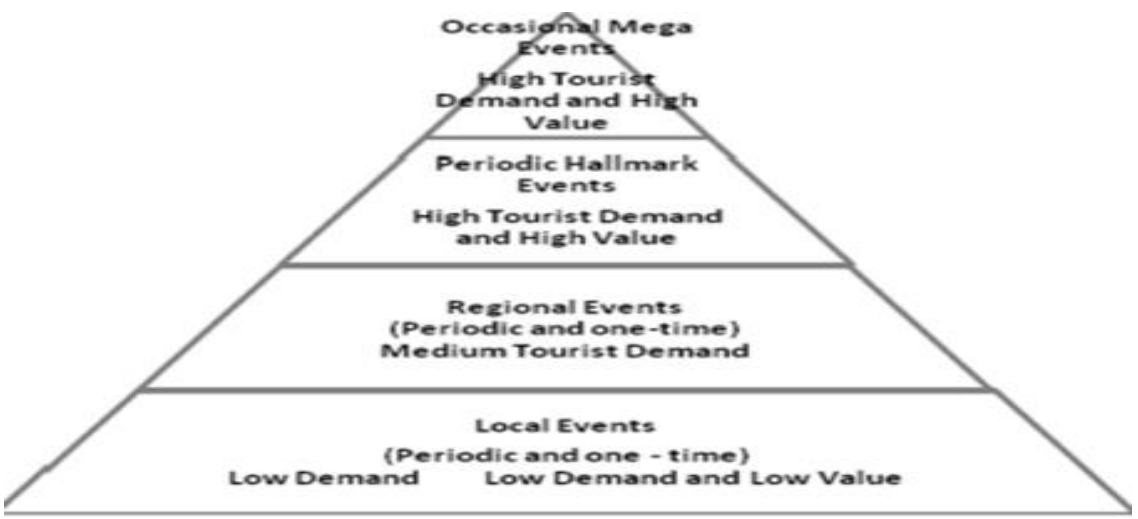

Figure 1 The portfolio approach to event tourism strategy - making an evaluation : Getz (2005)

Mega events are organized events with an impact on the national economy. They engage the entire national economy. Their contents are accompanied by an exceptional media attention. Influencing the economy and society under the community that are taking place (Allen et al 2005: 13), they are defined - "mega" because of the volume in the number of visitors (including the audience), the target markets, the level of public funding, the political impact of media coverage. Mega events were the subject of the AIEST-Cola World Conference (AIEST, 2017). Roche (2000; 2006) has studied the Olympics and mega events in the context of globalization but Hiller (2000) an urban-sociological perspective of mega events.

Hallmark event - refers to the kind of events that have become a symbol of a city or region, and they are identified with the event (brand) (Mardi Gras in New Orleans). They have become a synonym for the place, city or the region, and are characterized by recognisability and the stability (eg. Oktoberfest in Munich). They are organized in one or more times, with a limited duration, but primarily created to to increase awareness, of the attractiveness and the profitability of destinations (its image and brand), in a short and / or a longer period. With such events, the success and recognition are the results $t$ of their uniqueness, created in terms of specific destination identity (Ritchie, 1984). Regional events are important events that have been able to with regard to their coverage and media interest, attract a large number of visitors and achieve a significant economic impact.

The local events are held within the host community. By its purpose, it is primarily oriented to the the interests of entertainments of this the local population.These events, in addition to operate economically positive, above all, by strengthen local pride and self-awareness, support tolerance, and encourage participation in sports and cultural events.Such events are a part of almost every town and city, creating a sense of belonging to them. Local authorities support local events as part of their social and cultural strategies. In their organization, volunteers often participate from the host community. They are often held in public areas such as parks, streets and schools. The local authority participates in the organization of an event. Local event could evolve into a hallmark events and it could also attract more visitors to the community (Allen et al. 2011). 
Festivals and events seek for support and cooperation, influencing on approvement and its wider economic terms. The strategy emphasizes on tourist attractions, and using it to gain legitimacy and stimulating a growth. Events must provide material resources and political support to become sustainable, thereby losing a degree of independence in the process.

Table 1 An organized event according to the size

\begin{tabular}{|l|l|}
\hline Event Type & Description and features \\
\hline Mega events & $\begin{array}{l}\text { The largest organized events with effects and importance } \\
\text { on the level of international market. } \\
\text { Examples are the Olympics, FIFA World Cup. } \\
\text { Such events have a direct impact on tourism, media } \\
\text { attention and national economy. }\end{array}$ \\
\hline Hallmark events & $\begin{array}{l}\text { They become synonymous with the city, town or region } \\
\text { and are widely recognized } \\
\text { thematic recognizable and more specific }\end{array}$ \\
\hline Major events & $\begin{array}{l}\text { Aims to increase interest of tourists for a specific } \\
\text { destination or region. } \\
\text { Examples can be mentioned Carnival (such as Rijeka } \\
\text { Carnival) which attracts domestic and foreign tourists. } \\
\text { These events brings the city a significant financial benefits } \\
\text { and the promotion. }\end{array}$ \\
\hline Local events & $\begin{array}{l}\text { With their topics and the purpose are primarily intended for } \\
\text { local people as well as acting to create sense of } \\
\text { community and of belonging. }\end{array}$ \\
\hline
\end{tabular}

Source: Processing of authors

Even local events which are with its purpose directed primarily for local people provide a sense of identification og tourists with locals, giving them insight into the local tradition which contributes the better tourist experience (Brailo, 1995). Cultural changes and tourism are in an interactive relation. Culture is a measure of the value that an individual obtains on the basis the learning and perceptions. Culture influences the formation of specific motifs.

Observed over a longer period the culture is changeable, and adaptable. Cultural values influence on the tourism. Because of its variability they impact the new trends on which features are designed the new tourist products. It is a way of spending time. This confirme the fact of an increasing free time dedicated to entertainment. This affects the changes of values which are reflected in progress of materialism to self-actualization, from passivity to the interactivity, from quantity to the quality. It is significant in countries with higher level of living standards (Coates et al., 1997: 95).

Competitive conditions in the tourism market impose a global cultural identity, while at the same time, the specific interests of tourists intensely affect the need for profiling of innovative products. By investing in cultural events with the aim to restore the tradition of cultural theft, cultural changes are evident on the level of of opposing of the global cultural identity and the specific interests of potential consumers.

On the tourist market is evident shift in preferences from standard toward specific products in tourism. At the same time, further efforts are invested in activities that concentrate around anthropogenic factors in the area. Cultural celebrations, including entertainments, festivals, carnivals, religious events and arts, are usually classified under the Cultural Tourism in the literature. The main study of the Travel Industry Association of America (2003) profiled the cultural and historical tourists, including cultural events as attractions and activities. All types of planned events have tourist potential, even small weddings and meetings. But with a growing size and the importance of the event, it can also become a primary motif of tourists for visiting certain tourist destination 
According to Douglas N., Douglas S, Derr R. (2001: 3) - special Interest tourism, is defined as the phenomenon arising from customized recreational and leisure activities, expressed by the specific interests of individuals or groups. There are many definitions, but all share the significance tourist motives. Destinations offer are tailored for achieving the satisfaction of particular target segment. The selective tourism is considered from the viewpoint of supply and the demand (Kesar $\mathrm{O}$. 2012/2013).

Table 2 Classification of specific forms of tourism

\section{SPECIFIC FORMS OF TOURISM (based on next resources)}

\begin{tabular}{|c|c|c|}
\hline Natural resources & Social resources & Other resources \\
\hline $\begin{array}{l}\text { - Health Tourism (outdoor) } \\
\text { - Sports' tourism (adventure), } \\
\text { - Nautical tourism (sailing vs. cruise) } \\
\text { - Ecotourism (national parks or of } \\
\text { protected areas), } \\
\text { - Rural tourism (preservation of } \\
\text { traditional values), } \\
\text { - Hunting and fishing tourism (only } \\
\text { an organized form) } \\
\text { - Naturism (free relation between man } \\
\text { and the nature), } \\
\text { - Robinson's Tourism (in contrast to } \\
\text { the daily life), } \\
\text { - Camping (a return to nature) } \\
\text { - Team-building trips (raising of } \\
\text { communion) } \\
\text { - Photo-safari trips (photographing of } \\
\text { wild animals and of their habitats) } \\
\text { - Tourism resulting in combinations } \\
\text { of multiple activities in area) }\end{array}$ & $\begin{array}{l}\text { Health Tourism (outdoor) } \\
\text { - Sports' tourism (adventure), } \\
\text { - Congress tourism, } \\
\text { - Cultural (main motive of education) } \\
\text { - Gastro tourism (wine, food preparation } \\
\text { and consumption), } \\
\text { - Event tourism (entertainment, cultural, } \\
\text { economic) } \\
\text { - Religious toursim (pilgrimage, holy } \\
\text { places) } \\
\text {-Tourism based on artificially attractions } \\
\text { (amusement) } \\
\text { - Casino - tourism (gambling combined } \\
\text { with a shopping), } \\
\text {-Incentive travel (travel motivating for our } \\
\text { employee) } \\
\text { - The urban tourism (tourism of big cities) } \\
\text { - The film tourism (specific sites, } \\
\text { scenery), } \\
\text { - Party tourism ( } 24 / 7 \text { entertainment for } \\
\text { the younger population) }\end{array}$ & $\begin{array}{l}\text { Study tours } \\
\text { (Thematic travels) } \\
\text { - Shopping tourism, } \\
\text { - Business Travel } \\
\text { (Participants outside the business travel } \\
\text { programs behave as tourists) } \\
\text { - Historical tourism } \\
\text { (Motives are civilizational progress) } \\
\text { - An ethnic tourism } \\
\text { - The polar tourism } \\
\text { (Motivated activities in the Arctic Circle) } \\
\text { - The Escapism } \\
\text { ("Escape" from the domicile anywhere, } \\
\text { last-minute travel) } \\
\text { - The political type } \\
\text { (Political meetings), } \\
\text { - The post-war and a post-crisis types } \\
\text { (travel on post-war locations, often are } \\
\text { affected by natural disasters) } \\
\text { etc. } \\
\text { (Poge new age type } \\
\text { combines environmental protection with } \\
\text { - Virtual tourism } \\
\text { (Potija and famous destinations, }\end{array}$ \\
\hline
\end{tabular}

Source: Čavlek N. et.al. (2011).Turizam- ekonomske osnove i organizacijeski sustav; Školska knjiga, Zagreb, p.404.

The competitive attractiveness of tourist destinations can be created by affirming of cultural heritage (such as concerts, exhibitions, etc.), connecting the tourist offer with cultural identity (traditions, natural beauties and local customs), events, entertaining programs, all in order to attract a larger number of tourists, to extend the season and to improve an efficiency of managing values in destinations (Gračan and Rudančić - Lugaric, 2013). 


\section{Effects of Events}

Events affect the almost every aspect of human life, whether social, cultural, economic, environmental or political. They possess positive and negative ranges of influence to a particular destination and on business entities in the destination. Events are organized for various reasons. The most important are: satisfaction of social needs, the construction of facilities and infrastructures, the promotion of cities / countries, an increasing of tourist activities and various political reasons.

Among the core causes is the realization of various positive effects arising. It is necessary to develop and to maximize the positive effects, also to minimize the negative effects related to the maintenance of events.

As shown in Table 3, the positive and negative impacts of events act in areas of social, cultural, ecological, political and economic scope.

Table 3 The impact of organized events on the tourist destination

\begin{tabular}{|c|c|c|}
\hline $\begin{array}{l}\text { Effect of organized events on the } \\
\text { destination }\end{array}$ & Positive effects on the the destination & Negative impacts on the destination \\
\hline \multirow[t]{7}{*}{ Social and cultural } & Sharing of experiences & The social alienation \\
\hline & Revitalization of traditions & The manipulation of society \\
\hline & Creating of the social pride & The negative social image \\
\hline & Evaluation of social groups & Misbehavior \\
\hline & An increase in community participation & The social dislocation \\
\hline & $\begin{array}{l}\text { The appearance of new and the } \\
\text { challenging ideas }\end{array}$ & Global ideas \\
\hline & The expansion of cultural perspectives & Global identity \\
\hline \multirow[t]{5}{*}{ Physical and ecologically-viable } & $\begin{array}{l}\text { An emphasis of the environment - the } \\
\text { nature }\end{array}$ & \\
\hline & Providing the best models of practices & The loss of the comfort \\
\hline & $\begin{array}{l}\text { Improvement of the environmental } \\
\text { awareness }\end{array}$ & The destruction of the nature \\
\hline & $\begin{array}{l}\text { The improved transport and } \\
\text { communications }\end{array}$ & The noise pollution \\
\hline & Urban transformation and renewal & The traffic congestion \\
\hline \multirow[t]{4}{*}{ The political effects } & International prestige & Losing of prestige \\
\hline & The improved profile & $\begin{array}{l}\text { The risk of an unsuccessful organized } \\
\text { event }\end{array}$ \\
\hline & Improving of investments & $\begin{array}{l}\text { Erroneously allocation financial } \\
\text { resources }\end{array}$ \\
\hline & Social cohesion & The lack of of responsibility \\
\hline
\end{tabular}

Source: Bowdin, G. et al.(2006). Events management $2^{\text {nd }}$ ed. Oxford: Elsevier

Events have direct social and cultural impact of participants, including increased community pride, sharing of experiences, increased community participation. An organizing of events is an excellent opportunity to highlight the quality and specifics of the tourist destination. Positive physical and ecological effects are reflected in raising awareness on environmental 
protection and transformation, but also in the improvement of transport and communication infrastructure. On the other hand, the pollution of the nature is almost inevitable, as well as the noise and traffic congestion. By adopting the strategy of sustainable development in the organization of events as well as care for the environment, negative impacts can be greatly reduced or even eliminated, and thus to contribute to the reputation (image) of environmentally conscious of destinations (Gračan and Rudančić - Lugaric, 2013: 277).

Benefits are diverse. They are mostly seen thourg economic impacts. They have a high intensity power of attracting of visitors to an area (Getz and Cheyne, 2002; Mossberg, 2000). They can also generate travel to a specific destination after the event is over. Thus create value by selling innovative products that destination offers. Moreover, events can have an effect on creating of destination image, creating a more favorable perception of a particular area. A more positive image of the place has an impact on industrial investments. Moreover, events, especially the mega event, can play an important role in initiating the construction of infrastructure, trade and entrepreneurship, as well as urban renewal.

For many destinations events provide an additional public attention through extensive media coverage. Finally, one must not underestimate the social and cultural effects that events cause. Events serve a very important social purpose and offer to both tourists and local people an unusual experience. When you observe all the benefits of the event it becomes apparent that destinations have great potential in events. Accordingly, destination managers should be effectively engaged in tourism events. Thanks to the growing competitiveness of tourist destinations, the development of event has become a big business.

Factors influencing the development and creation of knowledge about tourism events could be found in specific needs, motivations, preferences, with assumptions such as free time and finantial resources. Social and cultural factors stimulate the creation of innovative and special events (Allen et al. 2002). Consequences of an event are obvious through the results and impacts of various dimensions as personal, social, political, cultural, economic and environmental impacts. Support for the creation of knowledge and the development of the theory of tourism events are models and processes of tourism events that defined spatial and temporal models, policy management and creation of knowledge in tourism events. Results, influential factors, models and processes of tourism events are associated in creation of knowledge in tourism events. The experience of tourism events is changing, by changing beliefs and attitudes towards values. Participants will adopt these changes in a new behavior in the future. The transformation of needs is influenced by experiences (Mihajlovic and Koncul, 2016). They are gained by tourism events, also as a part of social networking. Events have the meaning given by social groups, communities and society as a whole. This affects individuals but regardless they are able to make their interpretation of events.

\section{Activities focused on the competitiveness of SMEs in tourism sector on the Croatian}

\section{national level}

Given the economic effects and the contribution to the world economy, the tourism market with an impressive share participates in the global international context. Achievement of business goals for destinations depends on their abilities to meet the desires and needs of tourists. Tourists today are not loyal to the destination but the destination brand, whereby it is important its recognisability. A tourist interest is rotated from the standardized stay in the destination toward the natural and cultural features of travel as well as sports and entertainment facilities. Therefore, the tourist offer disperses on wider areasby creating tourism destination which is not administratively bounded. A tourist destination should be treated as an open and dynamic system that interacts: tourists, employees and the local population. There is a high degree of horizontal substitution. On the basis of different definitions, it is necessary to summarize the most important characteristics of a tourist destination: it makes the spatial whole of the tourist offer, it must have sufficient elements of the offer that is oriented towards the market, tourists, the destination must be managed by the experts.

Tourism represents an important engine of the economy, creating powerful effects of the multiplication, which are manifested in other economic areas. In 2013 , the share of tourism (in overall economic GDP) was estimated at $16.5 \%$. Two years later, tourism had a share of $20 \%$ of the total international receipts with 7.2 billion euros. This significantly reduced the foreign trade deficit of Croatia, covering $1 / 3$ of Croatian exports and $2 / 3$ of the export of services. Furthermore, in 2016, in Croatia was recorded 91, 3 million overnight stays, of which 80 million foreign overnight stays and 15,828,000 thousand tourist arrivals of which $88 \%$ foreign (Statistics, Ministry of Tourism, 2016). The number of permanent employed in tourism sector accounted for almost $10 \%$ of total employment. Concerning foreign direct investmentan an annual average of net flow of such investment was decreased from $6 \%$ of GDP In the period 1999 and 2008 to $2 \%$ of GDP in the period 
from 2010 to 2013, indicating a risk that a limited amount of investments could be forwarded to the trade and the production sector.

There needs to be circumstances changes and to attract foreign direct investment in production domestic assets and economic transformation, and to also to increase the impact of FDI in the sector of SMEs.

Networking and clustering can bring advantages for SMEs, particularly with regard to the strengthening of theirvalue and production chains. In Croatia, more than 500 companies are are involved in clusters that employ over 25,000 workers. A large share of the clusters is occupied by tourism and agriculture. In addition, there are one thousand five hundred and thirty-one registered cooperatives with over 21,000 members (CEPOR, SBA. 2016). Croatian SME's do not invest enough in innovation with the aim of introducing new products and services on the market. Croatia is considered as a "moderate innovator" with the percentage of companies involved in innovation 8\%, what's under EU average. Support will be offered the establishment of innovative newly emerging companies, but also improving the innovation and commercialization of activities of existing SMEs, particularly in areas referred in the development of: a) promotion of entrepreneurship, by facilitating the economic exploitation of new ideas and encouraging the creation of new businesses, including enterprise incubators; b) ensuring the better access to finance for SMEs; c) providing a favorable environment for the establishment and development of enterprises; d) supporting the capacity of SMEs for growth at regional, national and international markets and innovation processes; e) improving the development and growth of SMEs and innovativeness. The government has also realized the potential of manifestations in improving of their profile and the image of the host city as as well as the country where the event occurs. . It is also recognized the ability of organized events in attracting more visitors, which contributes to creating of economic benefits and the job creation. One of the most important impacts of tourism on the national economy is the revenue generated by organized events. In addition to the basic consumption at visits in an organized event, visitors visit the various sights in the host city, having additional expenses related to accommodations and other. Expenditures by tourists, and earned incomes, can have a significant impact on the local economy circulating therethrough as the revenue. An effective promotion of the destination through an organized event can result in extend length of stay of tourists, visiting other regional tourist destinations and their attractions.

In addition, the event itself may attract media attention and increase access to the destination that enhances the reputation (image) of the host city or tourist regions. Media exposures that successfully informed on event, may illustrate the quality of skills, innovation and achievements in relation to the host destination for the organizing of an event.

In terms of tourism, organized events cause many positive effects. Events have a major impact in diverting tourist trends with an attracting potential. Events influence on extending of tourist season, the average length of stay. Events increase revenue of host cities in accordance to increases the needs for new quality labor, reducing the unemployment, strengthening the competitiveness of destinations, improving of qualities of living for locals.

Positive effects of organized events have a high value on a scale of tangible and intangible values. Developing the longterm strategies of tourism, these results are visible through the overall contribution to the national tourist economics. (Gračan, Rudančić - Lugaric, 2013).

\section{Empirical Research}

The aim is to explore the impact of development of local event on the destination. Konavle as the municipality has 32 settlements where dominated both agriculture and tourism (Tourist Board of Konavle, 2016). Respondents as the target population were represented by the participants of this event, the host organizer, partners of the organizer, exhibitors, competitors and volunteers. In order to prove the hypothesis according to which $\mathrm{H} 1$ : Elements of of the local event as part of event tourism and cultural tourism impact on the identity of the micro-destination Konavle, empirical research was conducted on the basis of a survey on a sample of 60 respondents. An elementary unit research is the stakeholder of the local event.

\section{A.The Research Methodology}

Due to efficiency and more successful return of the number of filled questionnaires, the stakeholders were earlier contacted by by phone. Questionnaires were sent to them by e-mail. Number of returned, correctly filled questionnaires is 46 , or $76.67 \%$, which is a representative sample and it is sufficient for this type of of research. The composition of 10 issues (open and closed) is divided into three parts. The first one refers to the description of the profile, including general characteristics 
of respondents such as age, education and level of qualifications. Second part was presented with the specificities of participants of the local event (organizers, partners of organizers, exhibitors - family farms or some other type of association, volunteers), compared to their previous involvement and possible previous experiences in the rural tourism. The third issues refer to the assessment of competitiveness of stakeholders of local event, and the influence of elements of the event and rural tourism on the image of the destination development.

\section{B. Results}

By analyzing the demographic characteristics of respondents (Graph 1), it can be concluded that younger population dominates in the sample. The most frequent segment of the population are those from 18 to 26 years. As the age of the population increases, in such a way the percentage of older respondents declines.

Graph 1: Age of repodents

Source: Author's data processing

Graph 2 shows that the share of respondents with secondary school is $65.2 \%$. This is more than one half of respondents.

$2^{\text {nd }}$ graph shows that age is not proportional to the variable of educational degree, which indicates inadequately trained personnel. This thesis can be justified by the fact that most respondents are young that are currently on colleges.

Graph 2 Qualifications of respondents (\%)

\section{Source: Author's data processing}

Graph 3 shows the structure, the type of qualifications. It can be concluded that the largest part of the category are Others, which brings together many diverse professions. In accordance to the structure, the types of qualifications, it can be concluded that the largest part is the category - Others, which brings together many diverse professions. In the long run, even these "diversity" of qualifications is a good basis for further training of professional staff for the purpose of event tourism and of rural tourism. Rults support the earlier experience of stakeholders in events and of their involvement in rural tourism (because the this specific event has arisen from created tourist product of rural tourism Konavle).

Graph 3 Sample structure with respect to the particular level of education (\%).

Source: Author's data processing

Graph 4 Role of stakeholders and participants in the event

\section{Source: Author's data processing}

The biggest share (37\%) include competitors of the Festival "Zelena Menestra and the wine", then volunteers, exhibitors (growers, olive oil producers and other registered family agriculture economies), the organizers and their partners . Due to the scope, the environment of an event itself and the micro-destination in which is being held, problems of clear defined roles of participants should be taken into account. This means that partially exhibitors and / or competitors are also practically part the organizing team. The turnout of volunteers and competitors indicates the popularity of events among locals. The significance of this event spreads, entrapping the increasing number of of participants, during its maintenance. From last year , an attendance to this event has increased by $21.74 \% .15,21 \%$ of total number of participants, participated in the first year.

\section{Graph 5 Experience of stakeholders in rural tourism (\%)}

\section{Source: Author's data processing}

Findings point out (graph 5) that $80.4 \%$ of of stakeholders had no previous experiences in rural tourism which confirms the thesis that on the location of Konavle is just developing a rural tourism as one of the specific forms of tourism. The share of $19.6 \%$ of respondents has the experience through the registered trades, in organizing the excursions in destinations, within memberships in cultural art societies for the promotion of heritage, tradition and values of Konavle, by participating in fairs, but also in the cultivation and processing of indigenous products. 
Findings from graphs $6,7,8,9$ show levels of competitivness of stakeholders of the event, without a "competitor" and due to the fact that with this question tried to assess the overall organization among which are the organizers, their partners, exhibitors and volunteers.

Graph 6: Assessment of competitiveness of event organizers as stakeholders, from 1 to 5 (1- noncompetitive, 5extremely competitive)

Source: Author's data processing

Graph 7 An assessment of competitiveness of partner organisers as stakeholders

Source: Author's data processing

Graph 8 Assessment of competitiveness of exibitors as stakeholders

Source: Author's data processing

Graph 9 Assessment of competitiveness of volunteers

Source: Author's data processing

Top-rated are volunteers and exhibitors, then the organizers and the partners organizations. There is no marks (1-2); either very unnoticeable. For the purposes of argumentation of results, stakeholders can be divided into two groups,

So may examine isolated organizers and partners (as leaders of the organizing team) from exhibitors and volunteers (as a team). Observed in this way, leaders of the organizing team have achieved very good results. The most common shared mark is 5 (very competitive), followed by 4,3 and very insignificant percentage marks the second. These findings suggest successfully structured organizations by which all stakeholders of events are satisfied.

The remaining part of the organizing team, exhibitors and volunteers, are assessed mostly as a very competent what actually talking about their quality role in the overall organization.In such a way organizers and partners can be dissenting analyzed (as leaders of the organizing team) from exhibitors and volunteers (as a team). Observed in this way, leaders of the organizing team have achieved very good results. The most common joint score is 5 (very competitive), followed by 4 , 3 and very insignificant percentage of the mark 2. These findings speak in favor of successfully structured organizations by which all stakeholders are are satisfied. The rest of organizing team, exhibitors and volunteers, are assessed mostly as very competent what actually speak of its quality role of overall organization.

Graph 10 An influence of local event on the destination development

\section{Source: Author's data processing}

Graph 10 shows the results of evaluating of the impact of event tourism on destination development. For easier comprehension of issues, event tourism is defined in the context of makreting strategy aimed at implementation of potential economic benefits and values from events. From the results it can be concluded that event tourism has a role in development of destinations. This hypothesis is confirmed by $50 \%$ of respondents with a grade of an excellent, while slightly smaller percentages of respondents is assessed this hypothesis with a very good $32 \%$, and $12 \%$ with - good. Graph 11 shows the results show ann influence of local event on the image of destination

Graph 11 An influence of local event on the image of destination

\section{Source: Author's data processing}

Findings refer the impact of of local event on the destination image are assessedby respondents are with an extreme impact $(52.17 \%)$. Overall analyzed results create an image of a positive and successful impact on the further destination development and place identity, and thus on the image of Konavle as a micro-destination. From 46 of participants, 41 are engaged in activities that have contact with rural tourism. Here's coming to the interactivity, in accordance to the specific characteristics of two forms of selective tourism.

Graph 12 An assessment of influences of the local event on activities of Rural Associations (\%) 


\section{Source: Author's data processing}

Graph 12 shows the results of evaluating of influence of local events, as a part of tourist product, on the economic activities around which respondents are involved. $41.5 \%$ of them assessed assessed an influence as very good, $34.1 \%$ good, and $12.2 \%$ of them assessed it as an excellent mark. The reason for such small percentage of excellent ratings is a result of the tourist season, which affects the the local area.

Rural tourism is influenced by the seasonality. Instead of throughout the whole year it is measured only a few months during the year. Despite excellent assessment, influence of local events is assessed as very good for activities of respondents, because events and economic activities are regarded as a part of tourism. Featured results confirm the hypothesis according to which elements of of local events as part of cultural tourism, have an influence on the recognition of identity of Konavle as a micro-destination.

\section{Conclusion}

New market trends affecting the profiling of new marketing niche. Tourists are more informed, with special preferences, more conscious in perception of the quality. Competitors compete with prices and qualitaties, including the innovative services in offer, with a focus to the emotions and experiences. They put pressure on tourism industry to create new products, services and experiences. With potential factors contained within the motives, the demand must be directed towards a specific selective offer. Using values of the destination and perceiving them as comparative advantages that are selected, created and offered as specific tourist products, we must assure the destination develeopment and its imptoving that is under the sustainabilitiy concept.

Events are characterized by financial investments, limited time maintenance innovations, quality organization, a financial engagement, a limited time duration, careful planning. For the undisturbed implementation of planned topics of events, it is necessary to gather the organizational team. Each event is realized in interaction with the environment, which results in positive and negative effects in the destination host (on the local population, maintenance points) as well as business entities. Innovative modalities of tourism, that are dynamically experienced, are a response on the saturation of the standard products of mass tourism. Products such as events have advantages contained in the nature of events based on antropogenic resources.

Sustainable socio attractions are the basis to the creation of and organization of events, as cultural-historical, ethno - social, artistic and the ambiental activities. Positive characteristics of events are improving the living standards of local population through investments, the common participation of local stakeholders for pulic intersts, and possibilities of presenting of cultural heritage of the local area, creating an image of the host destination. Service providers and others engaged in the organization of an event through perceived values and positive experiences of event participants promote their services. This research confirms the main hypothesis about the impact of the elements of the local event within the event tourism in recognition enchanting. That argues that data refer on an increasing number of participants in the framework of this event Scents of Christmas as compared to 1 year maintenance. Although event tourism and rural tourism are defined separately, synergy is an incentive to encourage their further development of this region as a tourist destination. Thus, rural tourism is promoted in a manner that collects the autochtony of destinations. Maintenance of local events is important to create a positive image. Local events as innovations are still under development in Konavle

\section{References}

[1] AIEST (1987). The role and impact of mega-events and attractions on regional and national tourism, Vol. 28. St. Gallen, Switzerland: Editions AIEST.

[2] Agritourism Konavle. Available: http://www.agroturizam-konavle.hr/hr/udruga Accesed: [March 12 2017].

[3] Allen, J., O'Toole, W., Harris, R and McDonnell, I. (2005). Festival and special event management $3^{\text {rd }}$ ed. Australia: John Wiley and Sons.

[4] Allen, J., O'Toole, W., Harris, R and McDonnell, I. (2011). Festival and special event management $5^{\text {th }}$ ed. Australia: John Wiley and Sons.

[5] Bowdin, G., Allen, J., O'Toole, W., Harris, R. and McDonnell, I. (2006). Events management $2^{\text {nd }}$ ed. Oxford: Elsevier

[6] Brailo P. (1995), Ruralni turizam u okolici Dubrovnika, Turizam, 43(7-8):143.-148 
[7] Burns, J. and Mules, T. (1989). An Economic evaluation of the Adelaide grand prix, In G. Syme, B. Shaw, D. Fenton, \& W. Mueller (Eds.). The planning and evaluation of Hallmark events (pp. 172-185). Aldershot: GowerPublishing Co.

[8] Čavlek N. , Kesar, O., Prebežac, D. and Bartolucci M. (2011), Turizam- ekonomske osnove i organizacijeski sustav. Zagreb: Školska knjiga

[9] CEPOR (2016). Izvješće o malim i srednjim poduzećima u Hrvatskoj - 2015. GEM - Global Entrepreneurship Monitor istraživanja za Hrvatsku za 2014. CEPOR - Centar za politiku razvoja malih i srednjih poduzeća i poduzetništva, ISSN 1848-3526, Zagreb, travanj 2016. Available: http://www.cepor.hr/wpcontent/uploads/2016/06/Cepor-izviesce-2015-HR.pdf Accesed [17 March 2017].

[10] Coates, J.F., Mahaffie, J. B., Hines, A. (1997): 2025 Scenarios of US and global society reshaped science and technology. Greensboro NC. : Oakhill Press. Allen, J., O’Toole, W., Harris, R and McDonnell, I. (2002). Festival and special event management $2^{\text {nd }} e d$. Australia, Milton: Wiley.

[11] Douglas N., Douglas N, Derret R.; (2001), Special Interest Tourism. Australia: John Willey \& Sons

[12] Getz, D. (1989). Special events: Defining the product. Tourism Management, 10 (2): 135-137.

[13] Getz, D. (2005). Event management and event tourism. New York: Cognizant Communication Corporation.

[14] Getz, D. and Cheyne, J. (2002).Special event motives and behavior. In C. Ryan (Ed.). The tourist experience $2^{\text {nd }}$ ed. (pp. 137-155). London: Continuum.

[15] Getz, D.( 2007). Event Studies: Theory, research and policy for planned events. UK: Elsevier.

[16] Getz, D.(2008). Event tourism: Definition, evolution, and research, Progress in Tourism Management. Tourism Management. 29: 403-428.

[17] Gračan, D., Rudančić - Lugarić, A. (2013). Konkurentnost turističke destinacije - studija slučaja (case study) Riječki karneval, Ekonomski vijesnik, 26 (1): 271-282

[18] Hiller, H. (2000). Mega-events, urban boosterism and growth strategies: An analysis of the objectives and legitimations of the Cape Town 2004 Olympic bid. International Journal of Urban and Regional Research. 24(2): 439-458.

[19] Kesar O.(2012/2013), Uvod u specifične oblike turizma; Sveučilište u Zagrebu Ekonomski fakultet u Zagrebu Available: $\quad$ http://web.efzg.hr/dok/TUR/Web_Uvod\%20u\%20specifi\%C4\%8Dne\%20oblike\%20turizma.pdf Accesed [February 17 2017].

[20] Mihajlović, I., Koncul, N. (2016). Changes in consumer behaviour - the challenges for providers of tourist services in the destination, Economic Research-Ekonomska Istraživanja, 29(1): 914 - 937: Taylor \& Francis Group Routledge, (Online) Journal homepage: http://dx.doi.org/10.1080/1331677X.2016.1206683

[21] Ministarstvo turizma Republike Hrvatske. Izračun prema statistika za 2016. Available:http://mint.hr Accesed: [17 March 2017].

[22] Mossberg, L. (2000). Effects of events on destination image. In L. Mossberg (Ed.), Evaluation of events: Scandinavian experiences (pp. 30-46). New York: Cognizant Communication Corp.

[23] New Zealand Tourist and Publicity Department. (1987). New Zealand :Tourism Report No. 38 (November).

[24] Patkose, M., Stokes A. M. and Cook, S. D. (2003). The historic/cultural traveller. The Research Department of the Travel Industry Association of America: Washington, D.C.

[25] Ritchie J.R. B. (1984). Assessing the Impact of Hallmark Events: Conceptual and Research Issues, Journal of Travel Research. 23(1): 2-11

[26] Ritchie, J. R. B. and Beliveau, D. (1974). Hallmark events: An evaluation of a stratewgic response to seasonality in the travel market. Journal of Travel Research.14: 14-20.

[27] Roche, M. (2000). Mega-events and modernity: Olympics and expos in the growth of global culture. London: Roche, M. (2006). Mega-events and modernity revisited: Globalization and the case of the Olympics. Sociological Review. 54: 25-40.

[28] Turistička zajednica općine Konavle (2016). Available: http://visit.cavtat-konavle.com/hr/konavle Accesed [March 12 2017]. 